Development through Liberation 


\title{
Development through Liberation
}

\section{Third World Problems and Solutions}

\author{
Gerald J. Kruijer
}

Translated by Arnold Pomerans

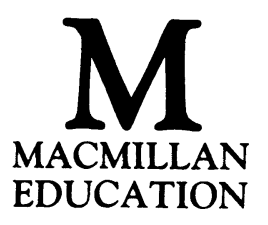


(C) the Estate of Gerald J. Kruijer 1987

Foreword (C) Ankie M.M. Hoogvelt 1987

All rights reserved. No reproduction, copy or transmission of this publication may be made without written permission.

No paragraph of this publication may be reproduced, copied or transmitted save with written permission or in accordance with the provisions of the Copyright Act 1956 (as amended), or under the terms of any licence permitting limited copying issued by the Copyright Licensing Agency, 7 Ridgmount Street, London WC1E 7AE.

Any person who does any unauthorised act in relation to this publication may be liable to criminal prosecution and civil claims for damages.

First published 1987

Published by

MACMILLAN EDUCATION LTD

Houndmills, Basingstoke, Hampshire RG21 2XS

and London

Companies and representatives

throughout the world

Typeset by Wessex Typesetters

(Division of The Eastern Press Ltd)

Frome, Somerset

British Library Cataloguing in Publication Data

Kruijer, Gerald J.

Development through liberation: third

world problems and solutions.

1. Developing countries-Economic

conditions

I. Title

330.9172'4 HC59.7

ISBN 978-0-333-40990-9

ISBN 978-1-349-18812-3 (eBook)

DOI 10.1007/978-1-349-18812-3 


\section{Contents}

Foreword by Ankie M.M. Hoogvelt ix

Introduction $\quad 1$

1 Poverty 7

The pattern of poverty 9

Psychological and social factors 13

Hoped-for improvements but poor prospects $\quad 13$

Uncertainty and fear $\quad 14$

Individualism 14

Underdeveloped organisational life $\quad 15$

Reactions to frustration $\quad 17$

All-out effort $\quad 18$

Hoping for a miracle $\quad 18$

Keeping up appearances $\quad 19$

$\begin{array}{ll}\text { Escape } & 19\end{array}$

Theft and violence $\quad 20$

Apathy 20

Some other reactions $\quad 21$

Economic attitudes $\quad 21$

Political attitudes $\quad 23$

Poverty and inequality $\quad 26$

2 Liberation Science 29

Introduction $\quad 29$

Solidarity groups $\quad 32$

The approach to science $\quad 34$

The view of man $\quad 35$

The social picture: a dialectical view $\quad 38$

Applied research $\quad 40$

Social criticism $\quad 42$

Change and continuity $\quad 42$ 
Central concepts $\quad 43$

Social problems $\quad 44$

Lack of power 45

Power $\quad 47$

Political and economic power 51

The liberation process $\quad 53$

Leadership $\quad 53$

Organisation $\quad 53$

Development and progress $\quad 55$

Macro/micro $\quad 56$

Decolonisation and the dismantling of elites 57

Action research $\quad 60$

Committed reports $\quad 62$

The research worker's frustrations $\quad 63$

Summary 65

3 The Poverty-and-Wealth System 67

Overview $\quad 67$

The regional system $\quad 69$

4 The National Poverty-and-Wealth System 73

$\begin{array}{ll}\text { Production } & 73\end{array}$

Overview $\quad 73$

$\begin{array}{ll}\text { The small producers } & 73\end{array}$

The middle-sized entrepreneurs $\quad 75$

$\begin{array}{ll}\text { The big businessmen } & 76\end{array}$

Social structure $\quad 77$

$\begin{array}{ll}\text { Social classes } & 77\end{array}$

The subproletariat $\quad 80$

The agricultural proletariat $\quad 81$

The factory workers $\quad 82$

The petty bourgeoisie $\quad 82$

The bourgeoisie $\quad 83$

Other structural elements $\quad 85$

The political system $\quad 86$

The cultural system $\quad 88$

Mass persuasion $\quad 89$

Introduction $\quad 89$

The mass media $\quad 89$

The church $\quad 90$

$\begin{array}{ll}\text { Education } & 91\end{array}$ 
Maintaining the system $\quad 92$ Introduction $\quad 92$

System maintenance $\quad 93$

5 The International Poverty-and-Wealth System 98 Introduction $\quad 98$

The drain of capital $\quad 99$

Unequal exchanges $\quad 101$

The brain drain 105

The capitalist world economy 105

Maintaining the system 115

The consolidation of inequality in economic power 116

Isolation of the poor countries 117

Strengthening the position of the rich countries $\quad 118$

Pseudo-progressive organisations 118

Holding out bait $\quad 119$

Cultural domination $\quad 119$

Social safety valves $\quad 120$

Violent oppression 120

6 Liberation Theory 121

Theories for rich and poor $\quad 121$

Towards a liberation theory 124

7 The Liberation Struggle 130

Introduction $\quad 130$

When is the time ripe? 132

Organisation and leadership 133

The driving forces 134

Allies 137

The role of women $\quad 140$

Political consciousness $\quad 142$

Cultural resistance $\quad 143$

Armed struggle $\quad 145$

Diplomacy $\quad 151$

Reaction 152

The Third World War for control of the Third World 155

Liberation struggle and development 157 
8 Development Strategy: General Aspects 163

Introduction 163

Socio-structural development strategy 164

Autochthonous, social and comprehensive development 167

$\begin{array}{ll}\text { Problems and solutions } & 169\end{array}$

The picture of the future $\quad 170$

The intermediate model 173

Party and state $\quad 174$

Spreading the national income 175

Medical care and education $\quad 176$

Mobilisation $\quad 178$

$\begin{array}{lr}\text { Production } & 180\end{array}$

Peasant holdings $\quad 183$

The vitalisation of culture $\quad 187$

Improvement of international relationships $\quad 189$

Capitalist strategy 194

The third path: the armed forces 195

9 Socialist Strategies 199

Introduction 199

Practice and theory 200

Ends and means 203

Two socialist structures $\quad 206$

Party and state $\quad 211$

People's power 212

The emancipation of women 214

Medical care and education $\quad 216$

Socialist mobilisation $\quad 217$

Production $\quad 220$

Culture 224

Improvement of international relationships $\quad 226$

Foreign enterprise $\quad 228$

World-wide prospects $\quad 229$

Notes and References $\quad 232$

Bibliography $\quad 242$

Index 253 


\section{Foreword}

It is not uncommon for sociologists to write about the poor and the oppressed. I sometimes think that our profession makes a good living out of it. But is rare to find us writing for the poor. To be sure, many of us write with a genuine sympathy and a concern to better the lot of the wretched of the earth. But such concern is often made subservient to the overriding need to stay within the rigorous parameters of scientific discourse. But how can a social science that is committed to value freedom and objectivity serve the needs of those who are oppressed by prevailing values and truths? How can the language of academia acquired through university education be used by those who never even finish school?

This dilemma is the key to Gerald Kruijer's lifelong work and this, his final, contribution to the struggle for liberation. The dilemma is not new, but the conviction and the passion with which it is resolved is.

Social science, Kruijer believed, will only serve the liberation of the poor if it liberates itself. It must liberate itself from the fruitless search for abstract concepts and timeless generalisations; from the neutering quest for unbiased objectivity and from its self-imposed sterile jargon.

Kruijer's science of liberation is about taking sides: that is, taking sides with the poor. Its starting-point is the real-life experiences of the poor, and it then proceeds to uncover, layer by layer, the debilitating structures of inequality and power which oppress the poor. The objective is to point to organizational, institutional and practical steps that can be taken - and indeed to point to those that frequently have been taken - to free the oppressed from their bondage.

Some readers may find the emotive language of this book an irritant. But the language is chosen to be a language that will reflect the experience of pain and struggle. For example, Kruijer argues that it is wrong to seek unemotional terms like 'unequal exchange' when laden terms like 'exploitation' convey so much better the experience 
of an indebted peasant suffering at the hands of a ruthless landowner or middleman. He argues that the liberation scientist should purposefully select a term or description that makes his/her viewpoint of anger or disapproval abundantly clear. This is the reason why the author shuns Marxist terminology with the same determination as with which he rejects the academic language of the bourgeois liberal tradition. Throughout he prefers the commonsense language of daily practice. The excellent translation from the Dutch by Arnold Pomerans has ensured that this objective has been wholly achieved.

Not everyone, not even some of those who share Kruijer's commitment and political conviction in broad outline, will agree with every detail of the substance of this work. Some, myself included, will recoil at the uncritical treatment of state socialist societies, particularly, for instance, the case of North Korea. Also, Kruijer's ahistorical and generalising perspective of the Third World, as a rather homogeneous group of nations in which economic and social development cannot take place as long as the umbilical cord with international capitalism has not been broken, is a perspective which I along with many others no longer regard as adequate in the restructured global political economy of the 1980s. Nevertheless the excellent descriptions of life in the Third World, covering all continents and gathered through personal travel and study, will deepen our understanding of the structures and processes that still dominate the lives of the masses of the population of the Third World, in whatever country, be it Brazil, South Korea or Ethiopia.

Kruijer died on 13 March 1986 . He had only just put the finishing touches to this revised English version of Bevrijdingswetenschap. Een partijdige visie op de Derde Wereld, first published in the Netherlands in 1983.

From his student days in the war-torn city of Amsterdam, where he was actively involved in the resistance to German occupation, to his polemical and strident work as writer and speaker for Third World campaign groups in retirement - as well as during his long and prolific career as an 'academic' professor in between - Kruijer has always consistently and passionately fought alongside and for the oppressed. A stimulating debater, a generous and encouraging friend, he will be missed by all who knew him well and whose lives and ideas he enriched.

Sheffield University

ANKIE M.M. Hoogvelt 